\title{
MEMBANGUN SISTEM KOMUNIKASI INDONESIA YANG KOLEKTIF LEWAT MEDIA TRADISIONAL
}

\author{
Mutiah \\ Prodi Ilmu Komunikasi \\ Fakultas Ilmu Sosial dan Hukum Universitas Negeri Surabaya \\ Email: Mutiah@unesa.ac.id
}

\begin{abstract}
Abstrak
Setiap era kepemimpinan tanah air memiliki corak sistem komunikasi tersendiri, yang paling segar dalam ingatan adalah sistem komunikasi satu arah yang digunakan rezim Soeharto, pola komunikasi masyarakat menjadi lebih tertutup dan terbatas inilah salah satu gambaran sistem komunikasi di tanah air. Saat ini perkembangan komunikasi Indonesia diramaikan dengan kuatnya pengaruh media digital yang nyatanya mengantarkan sistem komunikasi Indonesia menjadi lebih terbuka, banyak hal positif yang dapat perolah namun tak sedikit hal negatif pun berdampak pada pola perilaku komunikasi masyarakat di tanah air. Salah satu dampak negatif adalah perilaku hiperpersonality yang mengemuka, ujaran kebencian yang menjamur, kebebasan menebar berita hoax dan konflik-konflik sosial yang berawal dari isu-isu yang disebar lewat media digital. Artikel ini akan mengungkap media tradisional di tanah air yang merupakan media kolektivis masyarakat Indonesia. Indonesia adalah negara berkarakter gotong royong dan kolektiv dan ciri ini belum sepenuhnya pudar, masih banyak masyarakat yang mempertahankan media tradisional sebagai saluran kolektif untuk kepentingan bersama,memberi porsi kecil media baru masuk dalam lingkungan mereka. Artikel ini akan menyajikan gambaran media tradisional dibeberapa wilayah di Jawa Timur dengan metode penulisan deskriptif, mencoba memaparkan data hasil observasi dan wawancara kemudian penulis jelaskan dengan menyandingkan konsep Sistem Komunikasi Indonesia. Maka diperoleh kesimpulan bahwa media tradisional masih sangat efektif digunakan untuk membangun pola komunikasi yang kolektivis, bersama dan bergotong royong sesuai dengan karakter masyarakat Indonesia. Tentu dari artikel ini penulis memberi saran hendaknya pemerintah mengapresiasi tiap kelompok masyarakat yang memertahankan media tradisional sebagai media kolektivis dan kearifan lokal bangsa.
\end{abstract}

Kata Kunci : Sistem Komunikasi, Media Tradisional, Kolektivis, Masyarakat

\begin{abstract}
Every era has a style of leadership homeland of its own communication system, the most fresh in the memory is one-way communication system that use the Suharto regime, the communication patterns of society become more closed and limited to this one picture of the communication system in the country. Currently, the development of communication Indonesia enlivened by the growing influence of digital media are in fact deliver Indonesian communications systems become more open, a lot of positive things that can perolah but not less any negative impact on the behavior patterns of public communication in the country. One negative impact is raised hiperpersonality behavior, expressions of hatred which mushroomed, spreading freedom hoax news and social conflicts that originated from the issues that was distributed via digital media. This article will reveal the traditional media in the country which is a collectivist society Indonesian media. Indonesia is a country characterized by mutual cooperation and kolektiv and this characteristic has not completely faded, there are many people which maintains the traditional media as a collective channel for the common good, gave a small portion of the new media included in their environment. This article will present an overview of traditional media in some areas in East Java with descriptive writing method, trying to describe the data on observations and interviews later authors explain by juxtaposing concept Communication Systems Indonesia. It could be
\end{abstract}


concluded that the traditional media is still very effectively used to establish communication patterns collectivist, together and work together in accordance with the character of Indonesian society. Certainly from this article the authors advise the government should appreciate each community that preserves the traditional media as the media collectivist indigenous peoples.

Keywords: Communication Systems, Traditional Media, Collectivists, Society

\section{Latar Belakang}

Peristiwa pembuburan yang diduga dilakukan banser NU terhadap Takbliq Akbar di masjid shalahuddin, Gedangan Sidoarjo Jawa Timur merupakan peristiwa yang membelalakan mata umat muslim, hampir media sosial ramai dengan ungkapan yang menyesalkan peristiwa tersebut. Ustad Khalid Basalamah sebagai pengisi acara saat itu digiring kembali kekendaraannya, pembatalan ceramah yang dihadiri kurang lebih 2000 jemaah ini ditengarai kekawatiran NU bahwa isi ceramah yang akan disampaikan Ustad Khalid berisi pesan yang memprovokasi (tribunnews.com/2017/03/04/).

Tidak hanya pembubaran ceramah yang baru saja terjadi, ditahun 2016 peristiwa yang sama pun meramaikan pemberitaan TV Nasional Tanah air, pembuburan ritual Kebaktian Kebangunan Rohani (KKR) di gedung budaya Sabuga Bandung. Pembuburan ini dilakukan oleh Ormas Pembela Ahlus Sunnah (PAS), dengan indikasi belum ada izin yang jelas terhadap acara kebaktian rohani di Sabuga (http://www.cnnindonesia.com/nasional/2016).

Dua contoh peristiwa di atas merupakan gambaran bergesernya nilai-nilai budaya kolektiv dalam masyarakat kita. Dalam konteks komunikasi, pembubaran sendiri dapat dikatakan perilaku simbolik bermakna negatif yang mengarah pada tindakan orang atau kelompok tertentu secara sepihak. Pembubaran dalam konteks ini bukan pada konten faktor kenapa dibubarkan yang ingin penulis jabarkan, pada kurun waktu 2012 sampai 2017 budaya pembubaran menjadi alat ampuh untuk menghentikan kegiatan yang dianggap tidak satu pemahaman.

Penulis berpendapat bahwa kalimat pembubaran identik dengan aktivitas amoral. jika kita kaitkan dengan dua aktivitas diatas tentu kegiatan tersebut bukanlah kegiatan amoral, ceramah agama yang belum berlangsung bahkan ustad belum juga menyampaikan materi ceramah tentu tidak bisa dikatakan memprovokasi. Begitu pula pada ritual Kebaktian Kebangunan Rohani (KKR) digedung budaya Sabuga tidak dibenarkan pula dibubarkan hanya karena motivasi dugaan belum ada izin. 
Dalam sistem komunikasi kita mengenal tahapan masyarakat di Indonesia yaitu tradisional, kolektivis, dan individualis (Nurudin 2004: 21). Pada tahapan tradisional masyarakat Indonesia masih menggunakan media tradisional ditandai dengan aktivitas seni dan budaya seperti wayang, kentongan, ludruk dll. Media tradisional ini tidak sepenuhnya ditinggalkan oleh masyarakat kita masih banyak aktivitas tradisional tersebut dapat dijumpai dibeberapa daerah di tanah air. Media tradisional memungkinkan masyarakat mengakses secara bersama sama atau kolektif.

Seiring berjalannya waktu masyarakat kita aktif menggunakan media digital. Penggunaan media digital dianggap modern, modern disini diartikan masuknya masyarakat pada era akses informasi yang cepat dan penggunaan teknologi canggih. Jika merujuk pada makna tersebut artinya masyarakat Indonesia sudah dapat dikatakan pada masyarakat modern dengan penggunaan teknologi dan informasi, lewat penggunaan smart phone yang intensif masyarakat Indonesia sudah bisa mengakses informasi sebanyak mungkin dan hampir tak terbatas. Arus informasi dan teknologi sudah merambah kedesa-desa, lewat program pemerintah internet masuk desa tahun 2015 yang kemudian dilanjutkan pada tahun 2016 sampai sekarang. Berkembangnya teknologi khususnya pada aplikasi media sosial berbasis chating entah disadari atau tidak nampaknya telah menghantarkan masyarakat Indonesia pada sikap berlebihan.

Kondisi Sistem Komunikasi Indonesia bergeser ke budaya digital, bahkan pemerintah pun membaca fenomena ini dan memanfaatkan media sosial sebagai salah satu media untuk melayani masyarakat. Misalnya intensitas twitter yang digunakan Gubernur Jawa Tengah, Instagram yang digunakan Gubernur Jawa Barat, Facebook menjadi media publikasi perkembangan pemerintah Sumsel saat sebagai tuan rumah ASIAN GAMES dan tentu saja masih banyak lagi.

Penggunaan media sosial sebagai masyarakat modern, bukanlah hal yang salah hanya saja menurut pendapat penulis budaya komunikasi digital mengikis budaya kolekvis Bangsa Indonesia. Salah satu kegiatan komunikasi kolektif adalah penggunaan media tradisional, media tradisional adalah cerminan luhur Bangsa Indonesia yang berkarakter gotong royong. Ditengah era digital nyatanya masih ada beberapa wilayah yang mempertahankan budaya kolektif dalam berkomunikasi kelompok atau bermasyarakat. Maka lewat artikel ini peneliti ingin memaparkan eksitensi sistem komunikasi kolektif lewat media tradisional di Jawa Timur.

\section{Sistem Komunikasi Tradisional}


Media tradisional tumbuh dan berkembang menjadi media masyarakat, ciri dari media masyarakat adalah komunikasi dengan melibatkan pertemuan fisik, atau komunikasi antarpersonal. Hal ini dikarenakan masyarakat belum sepenuhnya perecaya menggunakan media digital dan media massa. Menurut Berrigan (dalam Nurudin,2007: 102-103 ) media masyarakat adalah sebagai berikut :

1. Media masyarakat adalah media yang bertumpu pada landasan yang lebih luas dari kebutuhan semua khalayaknya

2. Media masyarakat adalah adaptasi media untuk digunakan oleh masyarakat yang bersangkutan, apapun tujuan yang ditetapkan masyarakat

3. Media masyarakat adalah media yang memberi kesempatan kepada warga masyarakat untuk memperoleh informasi, pendidikan, bila mereka menginginkan kesempatan itu

4. Media ini adalah media yang menampung partisipasi masyarakat sebagai perencanaan, produksi, dan pelaksana

5. Media masyarakat adalah sasaran bagi masyarakat untuk mengemukakan sesuatu, bukan untuk menyatakan sesuatu kepada masyarakat

Lewat definisi dari media rakyat ini dapat dijelaskan fungsi dari media rakyat itu sendiri yaitu sebagai media yang memberikan alternatif sebagai sarana untuk rakyat mengemukakan kepentinngannya. Media masyarakat ini dapat pula menjadi jembatan untuk menghubungkan kesenjangan antara pusat dan masyarakat pinggiran. Media rakyat ini juga berfungsi sebagai penyeimbang pemihakan kepada perkotaan yang tercermin dalam isi media. Dengan adanya media tradisional ini juga membantu masyarakat desa dalam mengambil keputusan.

Media rakyat ini memegang prinsip dari, oleh dan untuk masyarakat pedesaan. Artinya media tersebut menjadikan kebutuhan informasri masyarakat sebagai hal yang utama. Media rakyat ini juga menjadi hal yang sangat berperan bagi masyarakat desa karena media rakyat ini mampu berakar kuat di masyarakat, lewat media rakyat inilah salah satu faktor berkembangnya suatu pedesaan. Sudah lama masyarakat pedesaan menggunakan media rakyat, baik media tradisional maupun media cetak, diawal tahun 1980 pemerintah telah melaksanakan koran masuk desa (Nurudin, 2007: 104-105). Banyak manfaat dari hadirnya koran masuk desa ini diantaranya meningkatkan keterampilan masyarakat desa terutama pada cara hidup dan memenuhi kebutuhan hidup. Hadirnya koran masuk desa ini juga berdampak pada motivasi masyarakat untuk mengubah nasibnya dan bergerak untuk berpartisipasi pada pembangunan dengan demikian mendorong masyarakat untuk kreatif dan inovatif dalam 
rangka meningkatkan kesejahteraan mereka. Arus komunikasi untuk masyarakat pedesaan pun lebih merata tentu arus informasi ini berlangsung baik dengan dukungan pemerintah dengan masyarakat dalam hubungan yang saling menguntungkan. Kendati koran masuk desa merupakan program pemerintah namun nyatanya dapat menjadi media rakyat yang efektif.

Ketika berbicara mengenai media tradisional dan kearifan lokal bangsa serta sistem komunikasi yang kolektif maka tidak bisa dilepaskan dari seni tradisional, karena lewat seni tradisional lah bentuk komunikasi kolektif bermula. Jika media massa artinya media yang menggunakan teknologi -terlepas teknologi yang sederhana atau kompleks- maka media tradisional menurut James Danandjaja (dalam Nurudin,2007: 114) merupakan alat komunikasi yang sudah lama digunakan disuatu tempat sebelum kebudayaan tersentuh oleh teknologi modern dan sampai sekarang masih digunakan di daerah itu. Adapun kontennya masih berupa lisan, gerak isyarat, atau alat pengingat dan alat bunyi-bunyian.

\section{Media dan Seni Tradisional}

Media tradisional tentu saja hasil dari menggali cerita-cerita rakyat kegiatan ini sering disebut folklor ada banyak bentuk folklor yaitu mite, legenda, dongeng yang merupakan cerita prosa rakyat. Selain itu ada juga ungkapan rakyat berupa peribahasa, pameo pepatah. Kemudian hadirlah puisi rakyat, nyanyian rakyat, teater rakyat, gerak isyarat, alat pengingat, alat bunyi-bunyian dan masih banyak lagi yang sampai sekarang masih digunakan masyarakat kita.

Jika ditinjau dari aktualisasinya banyak sekali praktek-praktek seni yang mengantarkan pada tujuan komunikasi kolektif diantaranya wayang purwa, wayang golek, ludruk, ketoprak seni-seni ini memakai peralatan atau media tradisional, kendati sudah masuk pada era digital seni tradisional ini tidak sepenuhnya ditinggalkan masyarakat terutama masyarakat pedesaan, di masyarakat pedesaan seni tradisional ini masih memegang fungsi media komunikasi kolektif prakteknya masih menggunakan peralatan tradisional. Sementara di perkotaan dengan mayoritas masyarakat modern seni tradisional ini telah bertransformasi mengikuti perkembangan jaman seni tradisional menyesuaikan dengan media massa modern. Artinya seni tradisional tidak lagi dimunculkan dengan bentuk yang apa adanya, melainkan telah memanfaatkan media televisi, radio, dan media interaktif atau internet.

\section{Komunikasi Kolektif Lewat Media Folklor}

Media tradisional sangat memungkinkan terjadinya komunikasi yang kolektif, dalam pengoprasian media tersebut saja tidak bisa dilakukan oleh satu orang, dengan karakternya 
yang menghasilkan bunyi-bunyian atau cerita dan gambar yang sarat akan cerita rakyat memberikan efek proksimiti bagi masyarakat itu sendiri. Dengan media tradisional proyeksi harapan masyarakat bisa di diperkuat sebagai alat pendidikan, sebut saja salah satunya adalah folklor. Folklor menjadi proyeksi angan-angan atau impian rakyat jelata atau sebagai pemuas impian masyarakat yang termanifestasikan dalam bentuk streotip dongeng.

Folklor dapat menjadi alat paksaan dan pengendalian sosial agar norma-norma masyarakat dipatuhi oleh anggota kolektifnya (Danandjaja , dalam Nurudin 2007: 115). Ada banyak sekali folklor di Indonesia seperti Bawang Merah dan Bawang Putih, Timun Emas, Batu Bela Batu Betangkup atau Nyi Roro Kidul. Semua folklor ini bukan cerita sebenarnya, hanya saja dalam cerita dongeng ini terselip angan-angan seorang gadis desa yang jujur, lugu, menerima apa adanya meskipun diperlakukan buruk. Atau angan-angan orang tua yang mengharapkan seorang anak berbakti namun diinginkan oleh raksasa yang jahat. Dua cerita ini menggambarkan ada pesan mendidik bahwa jika hidup jujur, baik pada orang lain maka imbalannya adalah sesuatu yang memuaskan dan menjadikan hidup lebih baik.

Folklor juga dapat mengandung cerita yang menguatkan adat rakyat, ada banyak sistem kerajaan yang bisa diangkat. Dengan kata lain mengangkat cerita kekuasaan memperlihatkan bahwa seseorang harus dihormati karena mempunyai kekuatan luar biasa yang ditunjukan lewat kekuatan ajaib seorang raja. Rakyat digambarkan memelihara rasa hormatnya kepada raja. Ada lagi cerita yang sangat ringan dan diwariskan turun temurun adalah katak yang congkak cerita ini merupakan alat paksaan dan pengendalian sosial terhadap norma atau nilai masyarakat. Cerita ini menyindir mereka yang banyak bicara sedikit bekerja.

Kelebihan folklor sebagai media tradisional dibanding media lain adalah media ini akan tumbuh dan berkembang dimasyarakat karena diwariskan turun temurun. Walaupun folklor adalah cerita dongeng namun dianggap sebagai cerminan kehidupan masyarakat desa. Folklor menjadi sarana komunikasi kolektif karena ceritanya yang menyentuh hati masyarakat. Media tradisional lewat folklor ini dapat saja efektif untuk menyampaikan pesan pembangunan, misalnya dalam pewayangan atau ketoprak. Media folklor hampir bisa dinikmati oleh semua lapisan masyarakat dengan jenjang pendidikan yang tidak perlu dibedakan. Pesan dalam folklor sifatnya lebih menghibur sehingga masyarakat lebih mudah menerima kandungan hikma didalamnya, selain itu lebih mudah mempengaruhi sikap masyarakat. Bahkan beberapa folklor dijadikan filosofi atau panutan hidup seseorang seni folklor dapat dinikmati dengan ringan tanpa harus berpikir keras. 


\section{Teknik Pengumpulan Data}

Dalam penulisan ini obeservasi dilakukan secara nonpartisipan, artinya penulis mengikuti aktivitas masyarakat namun penulis tidak lantas sebagai pengguna media tradisional yang digunakan masyarakat setempat. Pada awalnya keberadaaan penulis tidak diketahui, saat penulis ingin mendokumentasikan aktivitas mereka, maka penulis dibantu oleh mahasiswa dokumentasi dalam bentuk gambar, rekaman dan catatatan harian.

Hal terpenting dalam pengambilan data dari informan adalah menjelaskan dan menggambarkan media masyarakat yang digunakan warga setempat. Selanjutnya data juga dihimpun melalui wawancara. Wawancara menurut Mulyana (2004: 180): "secara garis besar terbagi dua, yaitu wawancara terstruktur dan wawancara tak terstruktur". Wawancara tak terstruktur sering juga disebut wawancara mendalam, wawancara intensif, wawancara kualitatif, dan wawancara terbuka. Metode ini bertujuan memperolah bentuk-bentuk tertentu informasi dari semua responden, tetapi susunan kata dan urutannya disesuaikan dengan ciriciri setiap responden (Mulyana, 2007: 181). Sehingga menurut Mulyana (2004, 181) "dari wawancara tidak terstruktur bentuk pengetahuan yang diperoleh dan validitas analisisnya didasarkan pada pemahaman yang dalam".

Data penulis analisis secara deskriptif, data yang sudah diperoleh dikumpulkan secara sistematis dan dianalisis secara kualitatif. Dalam artikel ini data yang telah dianalisis penulis sajikan dan jelaskan dengan mengaitkan pada literature sistem komunikasi tradisional.

\section{Membangun Komunikasi Kolektif lewat Media Tradisional di Jawa Timur}

Di Jawa Timur eksistensi media tradisional masih terjaga kendati relatif didaerah pedesaan, salah satunya di Dusun Durbug, Desa Batangan, Tanah Merah Bangkalan, Madura. Desa Batangan menurut cerita turun-temurun dari penduduk setempat berasal dari kata "bhethang" yang mempunyai arti bangkai. Konon di Desa Batangan adalah tempatnya para "blater" atau tokoh masyarakat yang sangat disegani karena ketangguhannya dalam urusan "Charok". Kata "Charok sendiri merupakan suatu istilah yang dapat diartikan sebagi suatu penyelesaian masalah melalui kekerasan atau perkelahian menggunakan senjata tajam celurit. Jadi bisa diartikan Desa Batangan adalah suatu tempat kejadian pembunuhan secara sadis para penjahat/ pencuri dengan cara dimutilasi dan kemudian potongan tubuhnya di gantung sehingga menjadi bangkai dan tinggal tulang belulangnya saja.

Keadaan komunikasi di Desa Batangan pada tahun 2017 ini udah bisa dibilang cukup modern untuk desa yang jarang dilewati oleh banyak orang dan juga tidak kalah canggih dengan komunikasi di kota besar. Sudah banyak yang menggunakan gadget untuk 
berkomunikasi dengan dunia luar dan mendapatkan informasi yang lebih banyak. Akan tetapi di Desa Batangan ini tetap menjaga media media komunikasi tradisional yang masih ada dan terus dijalankan sampai sekarang. Ada pun media tradisional di daerah ini yaitu kentongan, jika dikota kita sudah jarang meraskan fungsi kentongan tidak di Desa Batangan ini, masyarakat masih bergantung pada kentongan untuk memberitahukan keadaan darurat, untuk tanda berkumpul dan untuk petunjuk waktu. Ada pula Tok Otok merupakan media tradisional untuk merauk keuntungan/ mendapatkan kembali apa yang telah diberikan kepada semua orang yang telah diundang,seperti sesuatu dibalik amplop (selembar uang) yang jumlahnya dapat untuk mengganti bahan pokok yang telah terpakai untuk hajatan,ada pula yang menggantinya dengan beras,gula, dan telur. Pemberian itu semua tidak hanya diterima begitu saja melainkan dicatat di dalam buku pribadi yang nantinya akan menjadi hutang bagi pemilik hajatan kepada orang yang diundang. Sehingga pemilik hajatan harus membayar sama seperti apa yang diperolehnya. Perayaan ini biasa terjadi pada saat dilangsungkannya acara pertunangan,pernikahan dan khitanan . Sebagai simbol mereka bersyukur kepada sang Pencipta bahwa mereka dapat melaksanakan perintah-Nya.

Ada pula media tradisional di Dusun Jegles Kelurahan Blabak Kota Kediri. Di Dusun Jegles Kelurahan Blabak menggunakan musyawarah sebagai media komunikasi sangat mereka jaga dan rutin dilakukan. Mereka menganggap musyawarah masih sangat efektif hingga saat ini. Biasanya musyawarah diadakan para pengurus RT untuk membicarakan kegiatan apa yang harus dilakukan dan sebagai evaluasi kegiatan. Hampir diseluruh wilayah di Indonesia masih menjadikan media komunikasi kolektif kendati sudah berada di era digital. Selain musyarah di Kediri juga memilik media tradisional yang mampu menghadirkan khalayak yang banyak, yaitu festival brantas. Fesival ini selalu dilakukan setahun sekali untuk memperingati hari ulang tahun Kota Kediri, festifal ini selalu dipadati oleh ribuan masyarakat kendati mereka hanya menjadi penonton.

Pada festival ini ada acara tabur benih, yang menaburkan benih-benih ikan ke sungai berantas. Tentu tujuannya adalah memberikan pelajaran pada generasi muda bagaimana cara hidup yang ramah lingkungan, tak hanya mengambil hasil sungai tetapi juga menjaga ekosistem sungai. Dalam kegiatan tabur benih masyarakat berpartisipasi untuk membersihkan pinggiran sungai dan masyarakat pun antusias dalam kegiatan membersihkan sungai. Tak hanya itu dalam festival juga ada acara larung sesaji, merupakan gunungan hasil alam yang ditumpuk oleh panitia acara, tumpukan tersebut berisi umbi-umbian, padi, buah, sayuran. Yang ditumpuk menyerupai gunung-gunung kecil menjadi tiga bagian. Ada pula acara yang disebut jaranan, acara ini juga dikenal masyarakat sebagai hiburan yang beradegan debus. 
Selain adegan debus tersebut masyarakt sangat menanti kesenian tarian jaranan yang penarinya konon dirasuki arwah nenek moyang. Semua rangkaian kegiatan festival tersebut tidak lain wujud bersyukur kepada Tuhan yang Maha Esa atas limpahan hasil bumi yang dirasakan masyarakat Kediri.

Di Gresik pun ada media tradisional berbentuk folklor yaitu cerita rakyat Damar Kurung. Damar kurung merupakan sebuah media tradisional yang digunakan untuk mempererat persatuan suatu desa dalam kegiatan-kegiatan tertentu. Seperti ketika memperingati hari jadi sebuah desa. Damar kurung menjadi sebuah media yang digunakan pada saat pameran maupun festival. Damar kurung merupakan seni tradisional asli dari Kabupaten Gresik yang berupa sebuah lampion kertas dengan kerangka bambu yang pada sisi-sisinya dipenuhi oleh lukisan yang menceritakan tentang kehidupan sehari-hari yan tak sulit untuk dipahami. Ada suasana rumah tangga, pasar, jalan, masjid, dan pantai. Namun yang membuat damar kurung menjadi unik dari karya seni lainnya adalah cerita dalam damar kurung ini selalu bergerak dari kanan ke kiri, seperti tulisan dalam bahasa arab. Damar kurung masih memiliki eksistensi yang tinggi pada masyarakat luas karena lampu ini merupakan lampu khas Gresik yang hanya terdapat di Gresik. Dan lampu ini pun memiliki nilai keindahan tersendiri ketika dijadikan sebagai media tradisional. Tak hanya itu, damar kurung selalu menjadi daya tarik bagi masyarakat karena memiliki keunika tersendiri yang berbeda dengan lampu-lampu pada umumnya.

Di Surabaya pun masih ada wilayah yang menggunakan media tradisional, yaitu Jelidro Indah, Kec. Sambikerep, Kel. Sambikerep, Surabaya Barat. Media tradisional ini merupakan Gong alat musik khas Jawa, tetapi hanya digunakan sebagai pertanda kepergian atau meninggalnya seseorang. Media Tradisioal ini telah digunakan sejak sekitar awal tahun 1940 dimana warga pertama yang menetap di daerah ini memeperkenalkan penggunaan Gong tersebut. Pada mulanya, ada salah satu warga yang meninggal dunia, dan beberapa warga lain disekitarnya kebinggugan untuk memberitahukan kepada warga lainnya mengenai peristiwa tersebut, kemudian salah satu warga berinisiatif menggunakan Gong yang ada dirumahnya dan dipukulkannya sambil keliling ke rumah warga yang ada. Sampai saat ini Gong tersebut masih digunakan. Jika lazimnya meninggalkan salah seorang warga kita sering mendengar pengumumannya lewat alat pengeras suara di masjid, tapi tidak di Jelidro Indah Surabaya Barat.

Inilah sejumlah kecil masyarakat Jawa Timur yang masih menggunakan media tradisional sebagai sarana berkomunikasi. Komunikasi berfungsi untuk menghubungkan 
masyarakat dalam menanggapi lingkungan, media tradisional dapat menjembatani fungsi komunikasi tersebut karena dilakukan lewat komunikasi antapersonal, tetua kampung, atau pemuka pendapat yang menghadirkan suasana kolektif ditengah hadirnya media digital yang cenderung mengantarkan pada sifat individualis dan egois. Media tradisional tidak bisa dilepaskan dalam perannya membangun sistem komunikasi di Indonesia, karena komunikasi sendiri merupakan proses budaya, artinya komunikasi mau tidak mau selalu ditujukan pada orang atau kelompok lain sebagai bentuk bertukaran budaya dan didalam media tradisional terkandung proses komunikasi yang menyampaikan pesan-pesan budaya luhur.

\section{Kesimpulan}

Ada banyak cara yang dapat kita lakukan dalam membangun komunikasi mengantarkan kembali pada karakter masyarakat Indonesia yang kolektif. Kolekifitas yang dimiliki bangsa kita inilah yang mempererat persatuan didalam perbedaan suku bangsa, bahasa dan agama. Sistem masyarakat yang kolektifis ini menjadi bagian yang tak terpisahkan dari komunikasi. media-media tradisional yang sifatnya menghibur nyatanya bisa efektif menyampaikan pesan-pesan luhur budaya, pendidikan dan pembangunan. Pesatnya perkembangan teknologi komunikasi nyatanya tidak menyingkirkan media tradisional yang masih menjadi andalan satu-satu media komunikasi yang berhasil menciptakan kebersamaan ditengah masyarakat. Hal tersebut terbukti lewat beberapa festival daerah dari tahun ketahun selalu dilakukan, atau peralatan-peralatan budaya yang masih berfungsi, folklor yang terus diwariskan dari generasi kegenarasi sudah cukup memperlihatkan bawah masyarakat masih membutuhkan media tradisional sebagai wahana berkumpul sebagai masyarakat yang kolektivis.

\section{Referensi}

Devito, A Joseph. 1997. Komunikasi Antarmanusia. Jakarta : Professional Books

Moleong, Lexy J. 2006. Metodologi Penelitian Kualitatif. PT. Remaja Rosdakarya . Bandung

Mulyana, Deddy dan Solatun. 2008. Metode Penelitian Komunikasi: Contoh-contoh Penelitian Kualitatif Dengan Pendekatan Praktis. PT. Remaja Rosdakarya . Bandung

Nimmo, Dan. 2000. Komunikasi Politik. Bandung :PT Remaja Rosdakarya

Nurudin. 2007. Sistem Komunikasi Indonesia. Jakarta: Raja Grafindo Persada

Purwasito, Andrik.2015. Komunikasi Multikultural. Yogyakarta: Pustaka Pelajar 
Syam, W Nina. 2009. Sosiologi Komunikasi. Bandung: Humaniora tribunnews.com/2017/03/04/

http://www.cnnindonesia.com/nasional/2016

http://kbbi.web.id/bubar 